Acta Theriologica, Suppl. 3: 33-54, 1995.

PL ISSN 0001-7051

\title{
Enzyme heterozygosity and developmental stability
}

\author{
Jeffry B. MITTON
}

Mitton J. B. 1995. Enzyme heterozygosity and developmental stability. [In: Ecological genetics in mammals II. G. B. Hartl and J. Markowski, eds]. Acta Theriologica, Suppl. 3: 33-54.

Regular development of morphology is challenged by any environmental influence that draines energy from developing individuals. For half a century biologists have recognized that developmental stability, measured as the capability to regulate development of normal morphological structures, is influenced by genetic variation. This review considers the influence of enzyme polymorphism upon developmental stability. Empirical studies in a wide variety of animals have reported morphological variability and bilateral asymmetry to decrase with the heterozygosity of enzyme polymorphisms, A controversy focuses on the question of whether enzyme polymorphisms directly influence energy budgets and metabolism, or whether the enzymes are neutral markers that either reveal variation in levels of inbreeding or are in linkage disequilibrium with genes directly influencing development. Another controversy focuses on whether the relationships between enzyme heterozygosity and development stability, most commonly reported in poikilotherms, will also be found in homeotherms. These controversies are addressed by considering recent empirical studies of enzyme polymorphism and developmental stability. Kinetic and physiological studies have now established that enzyme polymorphisms can have a major impact upon flux through metabolic pathways and physiological variation. Enzyme heterozygosity is associated with resistance to parasites, which may decrease developmental stability. Enzyme heterozygosity is also related to secondary sexual characters, such as the size and symmetry of horns in white-tailed deer and the size of horns in bighorn sheep. Because symmetry is so important in sexual selection, the development of secondary sexual characters may yield important insights to the relationship between heterozygosity and developmental stability. Many empirical observations are consistent with hypothesis that enzymes have a direct influence on developmental stability. It is not likely that the relationship between heterozygosity and developmental stability will differ substantially between poikilotherms and homeotherms.

Department of Environmental, Population, and Organismic Biology, University of Colorado, Boulder, Colorado 80309, USA

Key words: enzyme heterozygosity, developmental homeostasis, fluctuating asymmetry, sexual selection, poikilotherms, homeotherms

\section{Contents}

Introduction

Enzyme heterozygosity and developmental stability 
Sexual selection 38

Symmetry is favored 39

$\begin{array}{ll}\text { Sexual selection favors heterozygous genotypes } & 40\end{array}$

Resistance to parasites $\quad 42$

Negative results $\quad 43$

Interpretations $\quad 43$

Neutral genetic markers

Enzymes catalyze metabolic reactions and regulate metabolism

$\begin{array}{ll}\text { Recommendations for future research } & 47\end{array}$

$\begin{array}{ll}\text { References } & 48\end{array}$

\section{Introduction}

Regular development is important to most if not all animals. Because form and function are intricately intertwined, morphological shape is related to performance, and ultimately to fitness. For example, the symmetry of the long tail feathers of the male barn swallow Hirundo rustica has a direct influence on flight performance and several components of fitness. Maneuverability in flight, which is critical for the ability of individuals to capture food and to avoid predators, decreases with both natural and experimentally-induced asymmetry of the tail (Møller 1991a). Consequently, the viability of males increases with the symmetry of the tail (Møller 1989, 1991b, 1994a, b). Similarly, the bilateral symmetry of thoroughbred racehorses predicts their ability to run, as measured by success at the track (Manning and Ockenden 1994).

Developmental stability is influenced by many variables. Pollution, stressful conditions during development, and poor nutrition all decrease developmental stability, and result in increased morphological variation and bilateral asymmetry. These relationships are so general that biologists now use bilateral asymmetry to monitor deterioration of environmental conditions and to detect environmental stress (Clarke 1992, Møller 1993, Manning and Chamberlain 1994). In addition to these environmental variables, developmental stability is also influenced by genetic variation.

The notion that developmental stability increases with heterozygosity is generally attributed to Lerner (1954), who described measures of performance and growth in inbred strains and the offspring of crosses among strains. In many studies, the variability in the hybrid progeny was lower than the variability in the pure breeding lines. Because $\mathrm{F}_{1}$ progeny are heterozygous for all loci fixed for alternate alleles in the pure breeding lines, Lerner concluded that developmental homeostasis increased with heterozygosity. The nature of the data reviewed by Lerner led biologists to expect developmental stability to reflect genome-wide heterozygosity, but studies within populations have demonstrated that development can be influenced by heterozygosity of specific chromosomes (Robertson and Reeve 1952), inversions (Dobzhansky and Wallace 1953), and in some cases, specific loci (Mitton 1978, 1993a, b, Eanes 1978, Leary et al. 1993). 
Developmental stability almost certainly responds to forms of genetic variation other than heterozygosity. For example, developmental stability may be enhanced by coadaptation (Clark et al. 1992), and modifying loci may canalize the development of specific morphologic characters (Waddington 1953). This review will not consider these mechanisms, but this exclusion does not deny their presence or significance.

This review starts by considering controversies concerning the relationships between heterozygosity and developmental stability. The association between enzyme heterozygosity and developmental stability is examined for animals in general, and for mammals in particular. Special attention is given to empirical studies of sexual selection and either developmental stability or enzyme heterozygosity. The review ends by considering interpretations of the empirical data and making suggestions for further research.

\section{Controversy}

A growing set of empirical observations suggest that developmental stability increases with allozyme heterozygosity in natural populations (Mitton and Grant 1984, Mitton 1993b). However, several points are controversial. First, some biologists assume that protein polymorphisms are selectively neutral, and then they proceed to use protein polymorphisms to estimate the relative heterozygosity of the entire genome. However, it is simply not possible to estimate the relative levels of heterozygosity at thousands of polymorphic loci with a few protein polymorphisms (Mitton and Pierce 1980, Chakraborty 1981). Controversy also focuses on the estimation of developmental stability; some studies use morphological variation, while other studies use fluctuating asymmetry to estimate developmental stability. Some biologists (Chakraborty and Ryman 1983, Leary et al. 1984, 1985) object to the use of morphological variation to estimate developmental stability, asserting that the estimate will be confounded by additive genetic variation. This objection would be appropriate if the marker genes directly influence the morphological traits measured, or if linkage disequilibrium was both extensive and strong, as it is in predominantly selfing species. However, the loci surveyed in electrophoretic surveys code for enzymes, not morphological characters. Furthermore, studies of developmental stability have employed outcrossing species, in which linkage disequilibrium is neither extensive nor strong, and therefore insufficient to explain a general phenomenon. Another disagreement concerns whether developmental stability would increase with enzyme heterozygosity in homeotherms, as it does in poikilotherms. Enzymes certainly respond to temperature, and poikilotherms undoubtedly develop in a greater range of temperatures than do homeotherms. But empirical studies suggest that if there is a distinction between poikilotherms and homeotherms, it is only in the degree of the influence of protein heterozygosity upon developmental stability. 


\section{Enzyme heterozygosity and developmental stability}

\section{Poikilotherms}

The first study of enzyme variation and developmental stability was conducted with the common killifish Fundulus heteroclitus (Mitton 1978). Fish collected from natural populations were divided into two groups, heterozygous and homozygous, for a single enzyme polymorphism. All comparisons were within sex and within populations. Morphological variation was estimated with seven meristic characters, and calculated either as the mean coefficient of variation or the determinant of the variance-covariance matrix. Within a locality and within sexes, heterozygotes were generally less variable than homozygotes.

Morphological variation decreases with allozyme heterozygosity in the monarch butterfly Danaus plexippus (Eanes 1978). Morphological variation was described with two characters, the length of the forewing and the diameter of the major forewing spot divided by the length of the adjacent wing vein. When the variances were compared between heterozygotes and homozygotes at a locus, heterozygotes had lower variances in 19 of 24 tests, and five of these reached statistical significance.

Morphological variation decreases with allozyme heterozygosity in the blue mussel Mytilus edulis (Mitton and Koehn 1985). Morphological variation was measured with 12 shell characters, and enzyme genotypes at four polymorphic loci were obtained for 103 mussels collected from a single site in the Cape Cod Canal. Morphological variation was summarized with principal components analysis. The heterozygosity classes did not differ in mean size, or in shape, but they differed in the variability of shape, with highly heterozygous individuals exhibiting the lowest variance in shape.

Developmental homeostasis increases with allozyme heterozygosity in a variety of salmonid fishes. This relationship was first revealed in a laboratory study of five bilateral characters and 42 polymorphic loci in rainbow trout Salmo gairdneri (Leary et al. 1983). The average number of asymmetric traits per individual declined with the expected allozyme heterozygosity for the full-sib family. Developmental homeostasis also increases with protein heterozygosity in natural populations of rainbow trout, in cutthroat trout Salmo clarki lewisi, and brook trout Salvelinus fontinalis (Leary et al. 1985).

Allozyme heterozygosity was associated with developmental homeostasis and other components of fitness in the guppy Poecilliopsis sp. (Beardmore and Shami 1979). Growth rate, viability and fecundity increased with individual heterozygosity. In addition, the variance of the number of caudal fin rays decreased with individual heterozygosity.

Enzyme heterozygosity is associated with both growth and developmental homeostasis in the herring Clupea harengus (King 1985). The mean length of fish increased with heterozygosity at five loci, and the asymptotic length of hetero- 
zygotes $(324 \mathrm{~mm})$ exceeded that of homozygotes $(308 \mathrm{~mm})$. In 70 comparisons of variances, homozygotes were more variable than heterozygotes in 49 comparisons, and 13 of these were statistically significant.

Fluctuating asymmetry of wings is related to genotypes at the MDH polymorphism in the honeybee Apis mellifera (Mitton 1993b, Messier and Mitton 1996). Within hives, heterozygotes have lower levels of fluctuating asymmetry than homozygotes, and the genotypes also differ slightly in the shapes of the wings.

Developmental stability increases with allozyme heterozygosity in the mosquitofish Gambusia holbrooki raised at a stressful temperature, but not in fish raised at their optimal temperature (Mulvey et al. 1994). Fish were raised in the labolatory under optimal $\left(25^{\circ} \mathrm{C}\right)$ and stressful conditions $\left(32^{\circ} \mathrm{C}\right)$. Heterozygosity was estimated with five polymorphic loci, and developmental stability was estimated with asymmetry at eight bilateral characters. Asymmetry decreased with heterozygosity in the fish raised at the high temperature, but not in the fish raised at the optimal temperature. Size increases with multilocus heterozygosity in mosquitofish raised at elevated temperatures (Feder et al. 1984, Lydeard et al. 1990, Mulvey et al. 1994), suggesting that allozyme heterozygosity confers a metabolic advantage at high temperatures.

Not all studies in poikilotherms have found consistent relationships between enzyme heterozygosity and developmental stability. Several studies in chum salmon and pink salmon have failed to reveal any consistent relationships between morphological variation and enzyme variation (Beacham and Withler 1985, 1987, Beacham 1991).

\section{Homeotherms}

Handford (1980) was the first to test for an association between allozyme heterozygosity and morphological variation in a homeotherm, but he found no relationship in the rufous-collared sparrow Zonotricchia capensis. However, his study was criticized for its small sample sizes and lack of statistical power (Eanes 1981). A subsequent study of the same species but with large samples $(n=479)$ yielded very different results (Yezerinac et al. 1992). Approximately 20 males were captured at each of 25 collection localities. Heterozygosity was monitored at 12 allozyme polymorphisms, and morphological variation was measured with eight external and twelve skeletal measurements. Among populations, morphological variation increased slightly with heterozygosity, indicating that the range of morphological variation increases with the level of genetic variation. Within populations, in 95 of 100 single locus tests, the variability of heterozygotes was less than the variation in homozygotes (sign test, $p<0.001$ ).

Results were heterogenous among loci, for comparisons with 6-phosphogluconate dehydrogenase did not reveal the differences revealed by the other loci. The low level of genetic variation, which is typical for birds, restricted multilocus comparisons to groups with 0,1 , and $>1$ heterozygous loci. Sixteen of twenty tests of homogeneity of variance were heterogenous among the heterozygosity classes, 
and the most heterozygous group consistently had the lowest level of morphological variability.

Enzyme heterozygosity is related to both size and the variability of shape in the house sparrow Passer domesticus (Fleischer et al. 1983). Size did not differ among the genotypes at any single locus, but size increased with individual heterozygosity in females, and in two of four analyses of males. Variances generally decreased with individual heterozygosity, so the most heterozygous birds tended to be both the largest and the least morphologically variable.

A study of enzyme heterozygosity and fluctuating asymmetry revealed no significant associations in the house mouse Mus musculus (Wooten and Smith 1986). Fluctuating asymmetry was measured with length of the body from snout to first caudal vertebra, weight of kidneys, and length and weight of testicles. All of these characters were metric variables, and all exhibited directional asymmetry, for measurements on the right side of the body exceeded measurements on the left.

Enzyme heterozygosity is related to developmental stability in the brown hare Lepus europaeus, in natural populations in Austria (Hartl et al. 1994, 1995). Measurements of fluctuating asymmetry were taken for 27 meristic traits and 9 metric traits from 469 hares taken from 20 populations. The genotype of each animal was identified at 39 enzyme loci. Enzyme heterozygosity was not related to the amount of morphological variation in populations, but enzyme heterozygosity was related to fluctuating asymmetry. Within populations, no consistent relationship was found between heterozygosity and fluctuating asymmetry. Among populations, heterozygosity was positively correlated with both fluctuating asymmetry of meristic characters $\left(r_{\mathrm{S}}=0.48, p<0.05\right)$ and metric characters $\left(r_{\mathrm{S}}=0.51, p<0.05\right)$ in juveniles. These relationships were opposite those reported for poikilotherms, and from those observed in adults. Among populations of adults, heterozygosity was negatively correlated with fluctuating asymmetry of meristic characters $\left(r_{\mathrm{S}}=-0.41, p<0.05\right)$, but not correlated with fluctuating asymmetry of meristic characters. The correlation between genetic variability and fluctuating asymmetry of meristic characters were stronger (juveniles: $r_{\mathrm{S}}=0.53, p<0.01$; adults: $r_{\mathrm{S}}=-0.67, p<0.01$ ) when genetic variability was estimated with the Shannon-Weaver information index rather than heterozygosity (Hartl et al. 1994).

\section{Sexual selection}

A substantial number of recent studies suggest that females use the symmetry of energetically expensive traits to assess the desirability of mates. Female choice sexual selection can elaborate conspicuous coloration, dance, display and vocalization in males (Bradbury and Andersson 1987). While some biologists have speculated that the characters elaborated by sexual selection are first chosen by female whim (Arnold 1985), other biologists have noted that females focus upon 
energetically-expensive mating advertisements (Kodric-Brown and Brown 1984, Møller 1990b). For example, the dance of the sage grouse at its lek and the hovering of the male Colias butterfly above its intended mate are really grueling endurance tests, not romantic displays. The horns of bighorn sheep and the antlers of deer advertise the acquisition and utilization of energy and resistance to parasites. If a female wishes to assess the energy budgets of her suitors, she might examine bilateral symmetry, for a substantial level of energy is needed to adequately buffer development.

\section{Symmetry is favored}

Empirical studies of horses, insects, and birds indicate that performance and competitive ability increase with bilateral symmetry. For example, running ability and symmetry are positively correlated in thoroughbred horses (Manning and Ockenden 1994). Performance in 73 flat-racing thoroughbred was estimated with the official ratings compiled by handicappers. Symmetry was estimated with the fluctuating asymmetry of 10 paired characters, four on the forelegs and six on the head. Although all of the correlations between ratings and fluctuating asymmetry were negative, the correlation was statistically significant only for the distance from the cheekbone to the mouth $\left(r_{\mathrm{P}}=-0.33, p<0.01\right)$. The correlation was stronger with the mean of the 10 measures of fluctuating asymmetry $\left(r_{\mathrm{P}}=-0.48\right.$, $p<0.001$ ).

Symmetry is better than size for predicting components of fitness in Japanese scorpionfly Panorpa japonica (Thornhill 1992). Male scorpionflies fight over dead arthropods, which they use as food and as nuptial gifts to secure copulations. The size and symmetry of forewings were measured in two natural populations in Japan. The winners of the fights for arthropods were more symmetric, but not necessarily larger than, the losers. Furthermore, the symmetry of mating males was higher than a random sample of males without mates, and asymmetry was correlated with the number of copulations secured by males $\left(r_{\mathrm{S}}=-0.84, p<0.001\right)$. Finally, survival in both males and females increased with symmetry.

The symmetry of the tail of the blue peacock Pavo cristatus increased with the size and number of ocelli, or eye spots (Manning and Hartley 1991). The tail is used in courtship displays, and male mating success increases with the number of ocelli in their tails (Petrie et al. 1991). Females mating with the males with the most elaborate tails bear offspring with superior viability (Petrie 1994).

Sexual selection acts on both the fluctuating asymmetry and length of the tail in the barn swallow Hirundo rustica (Møller 1994b). Barn swallows are small $(20 \mathrm{~g})$ aerial insectivores. Sexual dimorphism is slight, with the exception of the outermost tail feathers which are approximately $20 \%$ longer in males. In contrast with the general pattern seen in morphological characters, fluctuating asymmetry of the tail is high, and fluctuating asymmetry is negatively correlated with tail length (Møller 1990a) in males, but not in females (Møller 1994a). The length of the tail reflects environmental conditions, principally rainfall and food availability, 
during the winter, when the tail feathers are grown. The length of the tail generally increases during the first three years, as the males gain skill in searching for and capturing insects in flight. But the length of the tail also has a genetic component; parent-offspring comparisons yielded estimates of heritability to be $h^{2}=0.80+$ 0.33 for fathers and sons (Møller 1994b). Møller (1990b) has argued that the size and symmetry of the tail reliably reveal the physiological condition of male barn swallows. Maneuverability in flight declines with asymmetry of the tail (Møller 1991a), which results in a decline of viability (Møller 1991b), probably due to a decreased ability to capture flying insects. Females prefer males with long, symmetric tails (Møller 1988, 1990a, 1994a) and male mating success is highest in males with long, symmetric tails (Møller 1988, 1990a, 1994a). Finally, the length of the tail decreases with the load of two ectoparasites, the tropical fowl mite Ornithonysus bursa and the feather louse Hirundoecus malleus (Møller 1990c).

Why is symmetry related to performance and components of fitness, and why do females prefer symmetric males? Is the distance between the cheekbone and the mouth critical for the speed and endurance of a thoroughbred (Manning and Ockenden 1994), and is symmetry of the forewings critical to the fighting ability (Thornhill 1992) of scorpionflies? I belive that it is not the symmetry of these characters per se that causes components of fitness to increase with symmetry, and drives females to favor symmetric mates, but that it is the underlying cause of the symmetry which is important. Individuals who utilize food efficiently have higher probalities of buffering developmental processes to produce bilateral symmetry (Mitton and Koehn 1985). Metabolic efficiency increases with enzyme heterozygosity (Koehn and Shumway 1982, Hawkins et al. 1986, 1989, Garton 1984, Garton et al. 1984, Mitton 1993a, b), and consequently, symmetry generally increases with enzyme heterozygosity. It is the metabolic efficiency that permits some horses to run faster, some scorpionflies to fight better, and some peacocks and barn swallows to grow long, symmetric tails. The advantages of heterozygosity, including physiological efficiency and developmental stability, can be passed on to offspring, for individual heterozygosity is positively correlated between parents and their offspring (Mitton et al. 1993).

\section{Sexual selection favors heterozygous genotypes}

Male mating success of Colias butterflies is highly dependent upon their enzyme genotypes at the loci coding for Pgi, Pgm, and G6pd. Although females may mate as many as three times during their lives, a female uses the sperm from only a single male to fertilize eggs at any time. This aspect of the biology of Colias butterflies allowed careful analyses of the mating system in the field. Males and females were collected in the field, and transported to the laboratory. The males were genotyped immediately to provide an estimate of the genotypes of males attempting to mate. Females were placed in cages and allowed to lay eggs. The genotypes of both the female and her offspring were then examined to infer the genotype of the father (Watt et al. 1983, Watt et al. 1986, Carter and Watt 1988). 
This sampling design obtained estimates of genotypic frequencies for flying females, flying males, and males with reproductive success. The results were consistent over years, over collection localities, and for both $C$. eurytheme and $C$. philodice eriphyle. In the group of males attempting to mate, the frequency of Pgi heterozygotes was generally $40-45 \%$, but the frequency of heterozygotes in males with mating success ranged from $55 \%$ to $80 \%$. Similar results were obtained for the other loci. When the mating success of triple heterozygotes was set at 1.00 , the relative mating success of triple homozygotes was estimated to be 0.38 (Mitton 1993a). Both viability and egg production also increase with enzyme heterozygosity in Colias butterflies (Watt 1992).

Both male mating success (Zapata et al. 1990) and lifetime female fecundity of the brine shrimp Artemia franciscana increase with protein heterozygosity (Gajardo and Beardmore 1989). The most heterozygous female brine shrimp produce approximately ten times as many overwintering cysts as the most homozygous individuals.

Allozyme heterozygosity is related to many aspects of growth in white-tailed deer Odocoileus virginianus, alththough the influences of heterozygosity appear to vary among years, probably in response to environmental quality. The frequency of twinning increases with heterozygosity, and fetal growth rate increases with heterozygosity (Cothran et al. 1983). Spiked antlers, an abnormal, unbranched antler, decreases with age, body weight, and heterozygosity (Scribner et al. 1984). Body weight, kidney fat, the number of antler points, and main beam length/body weight increases with heterozygosity (Smith et al. 1982, Scribner and Smith 1990). Within an age class, $10-15 \%$ of the differences in main beam length, beam diameter, inside beam spread, number of antler points, and incidence of spiking are related to allozyme heterozygosity (Scribner and Smith 1990). The mean of the Boone and Crockett score, which quantifies the size and shape of deer horns, were $27 \%$ higher in highly heterozygous bucks in 1978 and 1979 , and were $17 \%$ higher in highly heterozygous deer than in deer with low heterozygosity.

To further examine the influence of enzyme heterozygosity on fetal growth in white-tailed deer, Leberg et al. (1990) replicated the study of Cothran et al. (1983) and extended the analysis to compare the growth rates of twins. Just as in the first study, the growth rates of non-twin fetal deer increased with their heterozygosities. However, because heterozygosity was not related to fetal growth rates in twins, Leberg et al. (1990) concluded that the protein loci were not responsible for the increase of growth rate with heterozygosity in single fetuses. However, other interpretations are consistent with these data. Because twins grow in a poorer, more crowded environment than singletons, differences in the fetal environment may explain the lack of a relationship between growth rate and heterozygosity in twins.

Horn growth in rams is related to allozyme heterozygosity in Rocky Mountain bighorn sheep Ovis canadensis canadensis (Fitzsimmons 1992, Fitzsimmons et al. 1995). Horns of males are used in displays, and as weapons and shock absorbers 
in collision fighting (Geist 1966). Horn size is important when males are struggling to establish their positions in the breeding hierarchy (Geist 1971, Hogg 1987). Hogg (1987) speculated that by choosing males with large horns, females gain mates of superior genetic quality, for both disease resistance and superior foraging ability are needed to grow large horns. Fitzsimmons et al. (1995) measured the horns of 113 bighorn rams taken by hunters in Wyoming in 1989 and 1990, and estimated the annual increase in the volume of the horns. Samples of tissue from each animal were analyzed with electrophoresis to identify their genotypes at four polymorphic loci. The sample was broken into two groups, those heterozygous for $0-1$ and those heterozygous for 2-4 loci. Multilocus heterozygosity accounted for $25 \%$ of the variability of growth in years 6 through 8 , a time when the growth in the highly heterozygous group was significantly higher than in the less heterozygous group. Growth rates did not differ significantly between the groups in the first five years of growth, or after year eight, although increases in horn volume in these years favored highly heterozygous rams. Rams typically begin to breed in year 7 or 8 , after two or three years of differential growth between the heterozygosity groups. Growth was related to heterozygosity at individual loci as well. The growth of heterozygotes significantly exceeded the growth of homozygotes for transferrin, glyoxalase, and lactate dehydrogenase. Symmetry of the horns was not related to heterozygosity (S. Buskirk, pers. comm.).

\section{Resistance to parasites}

Genetic variation at the locus coding for adenosine deaminase influences both parasite loads and survival in free-ranging Soay sheep Ovis aries (Albon et al. 1993). Adenosine deaminase plays a role in maintaining cellular immunity through the major histocompatibility complex. Heterozygotes at this locus had lower parasite loads and greater survival than homozygotes. Female choise has often been speculated to be a search for paternal genotypes resistant to parasites (Zuk et al. 1990). Enzyme heterozygosity is also associated with resistance to parasites in the snail Helisoma anceps (Mulvey et al. 1987) and rainbow trout (Ferguson and Drahushchak 1990).

Haptoglobin genotypes of the brown hare Lepus europaeus are associated with differential susceptibility to a variety of parasites (Markowski et al. 1990a, b). Brown hares were collected from 5 hunting areas in Poland, and tissue samples of the rectum, duodeum, gall bladder and the lung of 145 hares were examined for microorganisms of the genera Mycobacterium, Staphylococcus, Salmonella, and Candida. When hares were classified into uninfected and infected groups, the uninfected group had an excess of heterozygotes $\left(\chi^{2}=24.3, p<0.001\right)$, while the infected group did not deviate from equilibrium expectations. Among populations, the proportion of haptoglobin heterozygotes was correlated with the proportion of animals free of coccid infections $\left(r_{\mathrm{S}}=0.61, n=12, p<0.05\right)$. 
Allozyme genotypes of the alpine marmot Marmota marmota marmota are related to differential susceptibility to intestinal parasites (Preleuthner et al. 1995). An extensive allozyme survey of protein variation revealed polymorphisms at only super oxide dismutase $(\mathrm{Sod})$ and peptidase $(\mathrm{Pep})$ in populations in Austria. The restricted genetic variation is a consequence of repeated bottlenecks associated with reintroductions. Examination of the gastrointestinal tracts of 162 marmots revealed that $90 \%$ were infested with the cestode Ctenotaenia marmotae (range 1-1273 in infected marmots) and $62 \%$ were infested with the nematode Citellina alpina (range 1-1397 in infected marmots). Parasite loads were not related to Sod genotypes, but were related to Pep genotypes. Over $70 \%$ of the ss homozygotes were free of nematodes, but approximately $40 \%$ of the other genotypes were free of nematodes $(p<0.01)$. Approximately $30 \%$ of heterozygotes were free of cestodes, but less than $10 \%$ of the homozygotes were free of cestodes $(p<0.01)$.

\section{Negative results}

Hartl et al. (1991) found no relationship between protein variability and the developmental homeostasis measured by antler shape in red deer Cervus elaphus. Although growth of white-tailed deer has been reported to increase with hetrozygosity in several studies (Cothran et al. 1983, Chesser and Smith 1987, Leberg and Smith 1990), a study of 21264 deer over a 22 year period revealed no significant associations between heterozygosity and the asymptotic weight (Leberg et al. 1992). Bottini et al. (1979) found an association between birth weight and heterozygosity, but no relationship was found in a larger sample of children born in England (Ward et al. 1985). Kobyliansky and Livshits (1985) and Livshits and Kobyliansky (1985) reported morphological variability to decline with heterozygosity in human populations, but Livshits and Smouse (1994) reported no relationship in their study of elderly Israelis.

\section{Interpretations}

\section{Neutral genetic markers}

Numerous hypotheses have been proposed to explain the correlations between enzyme heterozygosity and developmental stability (Zouros and Foltz 1987, Mitton 1993b). The three most common hypotheses are: (1) enzyme polymorphisms are neutral markers that reflect variation in inbreeding, and the homozygous, more inbred individuals have less developmental stability; (2) enzyme polymorphisms are neutral markers in linkage disequilibrium with genes directly influencing developmental processes; (3) enzyme polymorphisms, through their control of metabolic processes and energy pools, influence developmental stability.

If either hypothesis 1 or 2 is correct, then heterozygosity at any neutral genetic marker, not just protein polymorphisms, should be correlated with variation in 
growth rate or developmental stability. This hypothesis was tested in a study of the scallop Placopecten magellanicus (Zouros and Pogson 1993, Pogson and Zouros 1994). Shell height was used to estimate growth rate, and heterozygosity was estimated with seven protein polymorphisms, two proteins of unknow function, five single-locus VNTRs, and three nuclear RFLP's. The correlation between heterozygosity at the seven enzyme loci and shell height was positive and significant $\left(r_{\mathrm{S}}=0.148, p<0.05\right)$, while the correlation between the 10 DNA markers and shell height was not significantly different from zero $\left(r_{\mathrm{S}}=0.032, p>0.50\right)$. Because the DNA markers did not reveal a correlation between heterozygosity and growth, the correlations between enzyme heterozygosity and growth are not attributable to either variation in inbreeding among individuals or linkage disequilibrium. This experiment suggest that at least some of the variation in growth rate in natural populations of scallops is attributable to genotypes at protein loci.

Studies of geographic variation have also revealed discordant patterns of variation between enzymes and DNA markers. Patterns of geographic variation and inferences about the magnitude of gene flow differ between protein polymorphisms and DNA markers in the American oyster Crassostrea virginica. Allozyme frequencies in oysters exhibit very little variation from Maine to Texas, a geographic pattern initially interpreted as evidence for extensive gene flow among populations of oysters (Buroker 1983). However, a survey of mtDNA variation revealed a striking discontinuity in mtDNA in northeastern Florida (Reeb and Avise 1990), and a subsequent study of nuclear RFLP's (Karl and Avise $1992)$ detected the same discontinuity revealed by mtDNA. The geographic pattern of mtDNA and nuclear DNA markers suggest very limited gene flow. Cleary, the estimates of extensive gene flow from allozymes and very limited gene flow from mtDNA cannot both be correct. After considering alternate hypotheses for the discordant patterns of geographic variation in oysters, Karl and Avise (1992) tentatively concluded that balancing selection acting upon enzyme loci caused this set of loci to diverge from the pattern of geographic variation exhibited by the mtDNA and nuclear RFLP's.

Allozyme polymorphisms and mtDNA also reveal discordant patterns of genetic variation in the deer mouse Peromyscus maniculatus (Avise et al. 1979, Lansman et al. 1983). Allelic frequencies at protein polymorphisms reveal slight to moderate population structure from central Mexico to central Canada, with values of $F_{\text {ST }}$ varying from 0.04 to 0.38 among six polymorphic loci. In contrast, mtDNA revealed five distinct geographic groups distinguished by diagnostic haplotypes. For example, the mtDNA haplotypes in the eastern states and northern Michigan differ from the haplotypes in the central states by approximately 20 mutational steps. The diagnostic differences in mtDNA mark absolute barriers to gene flow for cytoplasmically inherited markers. The shallow patterns of differentiation for allelic frequencies of protein polymorphisms contrast sharply with the dramatic, historic population structure revealed by mtDNA haplotypes. Enzyme polymor- 
phisms and DNA markers also show contrasting patterns of geographic variation in the Atlantic cod (Pogson et al. 1995), horseshoe crabs Limulus polyphemus, and several species of forest trees (Mitton 1994).

\section{Enzymes catalyze metabolic reactions and regulate metabolism}

If the genotypes segregating at a locus are to have differential impacts upon fitness, they must have different biochemical properties, or differential performance (Koehn 1978, Clarke 1975). Enzymes may differ in their interactions with membranes, substrates, cofactors, and other proteins. Depending upon the amino-terminal amino acid, the half-lives of proteins vary from a few minutes to more than 20 hours (Bachmair et al. 1986). Consequently, genotypes can vary in their enzyme turn-over rates, one of the major components of routine metabolic costs (Hawkins et al. 1986, 1989). Enzymes may also vary in their efficiencies for catalyzing metabolic reactions. Studies of enzyme kinetics typically focus upon the measurement of a series of catalytic variables, such as the maximum velocity $\left(\mathrm{V}_{\max }\right)$, the catalytic efficiency $\left(\mathrm{k}_{\mathrm{cat}}\right)$, and the Michaelis constant $\left(\mathrm{K}_{\mathrm{M}}\right)$, that relate to an enzyme's efficiency for catalyzing a reaction (Hall and Koehn 1983).

Evolutionary biologists have analyzed kinetic variation of several dozen enzyme, hemoglobin, haptoglobin, and transferrin polymorphsism (Frelinger 1972, Templeton 1982, Koehn et al. 1983, Watt 1983, Chappel and Snyder 1984, Hilbish and Koehn 1985, Pogson 1991, Powers et al. 1994). In the majority of the studies reported in the literature, kinetic differences are found among the segregating genotypes. Because there are probably biases in the selection of polymorphisms for kinetic analyses and in the publication of results, it would be difficult to determine what proportion of extant polymorphisms have significant kinetic variation.

The kinetic variation among enzyme genotypes has been shown to influence flux through metabolic pathways or the accumulation of metabolic intermediates in the sea anemone Metridium senile (Zamer and Hoffman 1989), the copepod Tigriopus californicus (Burton and Feldman 1983), the fruit fly Drosophila melanogaster (Cavener and Clegg 1981, Eanes 1984, Labate and Eanes 1992), Colias butterflies (Watt 1992), the blue mussel Mytilus edulis (Hilbish and Koehn 1985), the killifish Fundulus heteroclitus (Powers et al. 1994), and the tiger salamander Ambystoma tigrinum (Carter 1993). Kinetic variation among enzyme genotypes has been reported to be associated with some aspect of whole-animal physiology or performance in T. californicus (cell volume regulation; Burton and Feldman 1983), D. melanogaster (power developed during flight; Barnes and Laurie-Ahlberg 1986), Colias eurytheme (survival, flight temperature, fecundity; Watt 1992), $F$. heteroclitus (hatching time, swimming endurance, rate of development; Powers et al. 1994), M. edulis (cell volume regulation; Hilbish and Koehn 1985), A tigrinum (oxygen consumption and metamorphosis; Mitton et al. 1986, Carter 1993). 
Resting oxygen consumption decreases with enzyme heterozygosity in the American oyster Crassostrea virginica (Koehn and Shumway 1982), the gastropod Thais hemostomata (Garton 1984), the coot clam Mulinia lateralis (Garton et al. 1984), the rainbow trout Salmo gairdneiri (Danzmann et al. 1987, Danzmann 1988), the blue mussel M. edulis (Diehl et al. 1985, 1986) and the tiger salamander A. tigrinum (Mitton et al. 1986). These reports are sufficiently numerous, and the taxa are so diverse that they lead me to assert that the relationship is general for poikilotherms. A single study of enzyme heterozygosity and basal metabolic rate has been conducted in a mammal (P. A. Carter, pers. comm.). Basal metabolic rate, $\mathrm{VO}_{2 \max }$, sprint speed and endurance were measured on $317 \mathrm{HSD} / \mathrm{ICR}$ house mice Mus domesticus in the labolatory of T. Garland at the University of Wisconsin. Electrophoretic analyses identified the genotype of each mouse at six polymorphic loci: Pgi, Pgm, $6 P g d, G o t, M d h$, and $M p i$. Individual heterozygosity was not related to $\mathrm{VO}_{2 \max }$, or sprint speed or endurance, but basal metabolic rate increased with individual heterozygosity $\left(r_{\mathrm{S}}=0.16, p<0.01\right)$. This correlation is positive, while the studies in poikilotherms all revealed negative correlations between individual heterozygosity and routine metabolic costs.

The decrease in resting oxygen consumption with enzyme heterozygosity in poikilotherms and the opposite relationship in homeotherms suggest that enzyme heterozygosity confers some energetic advantage. Physiologists infer from these data that the routine metabolic costs of heterozygotes are lower than those of homozygotes. Protein turnover rates (Hawkins et al. 1986, 1989) are lower in heterozygotes than in homozygotes, and this difference has a direct effect upon routine metabolic costs. The energetic advantage of heterozygosity is seen in the faster growth rate and higher fecundity of a wide range of animals, mostly poikilotherms (Mitton 1993a). However, enzyme heterozygosity has been related to energetic advantages in the white-tailed deer Odocoileus virginianus. Heterozygosity at nine polymorphic loci is related to body size and reproduction (Scribner et al. 1989, Scribner and Smith 1990, Smith et al. 1991). In a study of 558 bucks hunted at the Savannah River Ecology Lab in 1978 and 1979, body mass, kidney fat, and rate of twinning increased with heterozygosity. Highly heterozygous individuals had slower growth during the early years, but had greater asymptotic body mass and fat levels (Scribner et al. 1989).

The energetic advantages provided by high heterozygosity will sometimes, but not always, confer greater developmental stability (Mulvey et al. 1994). I suspect that energy is the common currency to these studies of heterozygosity and growth and development (Mitton and Koehn 1985, Alekseeva et al. 1992, Ozernyuk et al. 1992, Mitton 1993b). We know that virtually any stress during development-whether it is parsite load (Polak 1994, Møller 1994a) extreme temperature during development (Alekseeva et al. 1992, Ozernyuk et al. 1992), insufficient food, poor nutrition, or some form of environmental pollution (Clarke et al. 1986, Clarke 1992, Møller 1993, Manning and Chamberlain 1994) - can decrease developmental stability, increasing phenotypic variation and bilateral asymmetry. When animals 
are raised under optimal conditions, with abundant food, I expect that heterozygosity would be unrelated to developmental stability, for all genotypes have sufficient energy to buffer developmental processes. It is when conditions are less than optimal that heterozygosity could influence developmental stability. The advantages of metabolic efficiency conferred by heterozygosity would only make a difference when conditions challenge the energy budgets of developing genotypes (Koehn and Bayne 1988). For example, the absorption of food by mice does not vary among genotypes when food quality is high or intermediate, but when food quality is low, absorption efficiency increases with enzyme heterozygosity (Teska et al. 1990). Similarly, enzyme genotypes are not related to the growth rates of the earthworm Eisemia foetida under ideal conditions, but growth rates are related to genotypes in stressful environments (Diehl 1989).

\section{Recommendations for future research}

Numerous studies in poikilotherms have reported resting oxygen consumption to decline with enzyme heterozygosity, indicating that routine metabolic costs decline with enzyme heterozygosity. The first study in a homeotherm found the opposite relationship. We should determine whether the study of mice will be general for homeotherms, and if it is, we will want to better understand the distinct difference between poikilotherms and homeotherms.

A variety of studies of sexual selection indicate that females prefer mates with high levels of symmetry for sexually selected characters, and numerous studies indicate that morphological variability and asymmetry decrease with enzyme heterozygosity. But very few studies have examined the relationship of asymmetry and heterozygosity in sexually selected characters. Are females choosing mates with high levels of heterozygosity? This question could be examined in barn swallows, peacocks, scorpionflies, and other species in which female choose mates with high levels of developmental stability.

Fluctuating asymmetry declines with enzyme heterozygosity in a variety of animals. Most biologists attribute this relationship not to the direct influence of the enzymes, but to loci in linkage disequilibrium with them, or to variation in inbreeding in the population. If the enzymes are, indeed, neutral markers, then morphological variability and fluctuating asymmetry should decrease with heterozygosity with any set of neutral genetic markers. We now have the tools to compare the relationships of enzyme and DNA heterozygosity to developmental stability. In the first study comparing the correlations between growth rate and heterozygosity (Zauros and Pogson 1993, Pogson and Zauros 1994), the protein and DNA markers revealed different relationships, suggesting that the enzymes were not neutral markers. This experimental design should be applied to studies of developmental homeostasis.

The study of the European brown hare (Hartl 1994, 1995) should serve as a model for future studies of fluctuating asymmetry. It clearly demonstrates that 
relationships may differ between quantitative and metric characters, and that sampling should be stratified with respect to age class. Decreasing fluctuating asymmetry with age has also been reported for the antlers of white-tailed deer (Smith et al. 1982) and the skulls of cotton rats (Novak et al. 1993).

\section{References}

Albon S. D., Clutton-Brock T. H., Price O. F., Genfell B. T., Pemberton J. M. and Gulland F. M. D. 1993. Towards a more exact population demography. [In: Wildlife 2001: Populations. D. McCullough, ed]. American Elsevier Publishing Co., Inc., New York.

Alekseeva T. A., Zinichhev V. V., and Zotin A. I. 1992. Energy criteria of reliability and stability of development. Acta Zoologica Fennica 191: 159-166.

Arnold S. J. 1985. Quantitative genetic models of sexual selection. Experientia 41: 1296-1310.

Avise J. C., Smith M. H. and Selander R. K. 1979. Biochemical polymorphism and systematics in the genus Peromyscus. VII. Geographic differentiation in members of the truei and maniculatus species groups. Journal of Mammalogy 60: 177-192.

Bachmair A., Finley D. and Varshavsky A. 1986. In vivo half-life of a protein is a function of its amino-terminal residue. Science 234: 179-186.

Barnes P. T. and Laurie-Ahlberg C. 1986. Genetic variability of flight metabolism in Drosophila melanogaster. III. Effects of GPDH allozymes and environmental temperature on power output. Genetics 112: 267-294.

Beacham T. D. 1991. Developmental stability, heterozygosity, and genetic analysis of morphological variation in pink salmon (Oncorhynchus gorbuscha). Canadian Journal of Zoology 69: 274-278.

Beacham T. D. and Withker R. E. 1985. Heterozygosity and morphological variability of chum salmon (Oncorhynchus keta) in southern Columbia. Heredity 54: 313-322.

Beacham T. D. and Withker R. E. 1987. Developmental stability and heterozygosity in chum (Oncorhynchus keta) and pink (Oncorhynchus gorbuscha) salmon. Canadian Journal of Zoology 65: $1823-1826$.

Beardmore J. A. and Shami S. A. 1979. Heterozygosity and the optimum phenotype under stablising selection. Aquillo ser. Zoology 20: 100-110.

Bottini E., Gloria-Bottini F., Lucarelli P., Polzonetti A., Santoro F. and Varveri A. 1979. Genetic polymorphisms and intrauterine development: Evidence of decreased heterozygosity in light for dates newborn babies, Experientia 35: 1565-1567.

Bradbury J. W. and Anderson M. B. 1987. Sexual selection: Testing the alternatives. John Wiley and Sons, New York: 1-308.

Buroker N. E. 1983. Population genetics of the American oyster Crassostrea virginica along the Atlantic coast and the Gulf of Mexico. Marine Biology 75; 99-112.

Burton R. S. and Feldman M. W. 1983. Physiological effects of an allozyme polymorphism: Glutamate-pyruvate transaminase and response to hyperosmotic stress in the copepod Tigriopus californicus. Biochemical Genetics 21: 239-251.

Carter P. A. 1993. The evolutionary genetics of alcohol dehydrogenase in tiger salamanders. Ph D thesis, University of Colorado, Boulder, Colorado, USA.

Carter P. A. and Watt W. B. 1988. Adaptation at specific loci. V. Metabolically adjacent enzyme loci may have very distinct experiences of selective pressures. Genetics 119: 913-924.

Cavaner D. R. and Clegg M. T. 1981. Evidence for biochemical and physiological differences between enzyme genotypes in Drosophila melanogaster. Proceedings of the National Academy of Sciences USA 78: $4444-4447$.

Chakraborty R. 1981. The distribution of the number of heterozygous loci in an individual in natural populations. Genetics 98: 461-466. 
Chakraborty R. and Ryman N. 1983. Relationship of mean and variance of genotypic values with heterozygosity per individual in a natural population. Genetics 103: 149-152.

Chapell M. A. and Snyder L. G. R. 1984. Biochemical and physiological correlates of deer mouse alpha-chain hemoglobin polymorphism. Proceedings of the National Academy of Sciences USA 81: 5484-5488.

Chesser R. K. and Smith M. H. 1987. Relationship of genetic variation to growth and reproduction the white-tailed deer. [In: Biology and management of the Cervidae. C. M. Wemmer, ed]. Smithsonian Institution Press, Washington D.C.: $167-177$.

Clarke B. 1975. The contribution of ecological genetics to evolutionary theory: detecting the direct effects of natural selection on particular polymorphic loci. Genetics 79: 101-108.

Clarke G. M. 1992. Fluctuating asymmetry: a technique for measuring developmental stress of genetic and environmental origin. Acta Zoologica Fennica 191: 31-35.

Clarke G. M., Brand G. W., Whitten M. J. 1986. Fluctuating asymmetry: a technique for measuring developmental stress by inbreeding. Australian Journal of Biological Sciences 39: 145-153.

Clarke G. M., Oldroyd B. P. and Hunt P. L. 1992. The genetic basis of developmental stability in Apis mellifera: heterozygosity versus genic balance. Evolution 46: 753-762.

Cothran E. G., Chesser R., Smith M. H. and Johns. 1983. Influences of genetic variability and maternal factors on fetal growth in white-tailed deer. Evolution 37: 282-291.

Danzmann R. G. 1988. Heterozygosity and components of fitness in a strain of rainbow trout. Biological Journal of the Linnean Society 39: 285-304.

Danzmann R. G., Ferguson M. M. and Allendorf F. W. 1987. Heterozygosity and oxygen-consumption rates as predictors of growth and developmental rate in rainbow trout. Physiological Zoology 60: 211-220.

Diehl W. J. 1989. Genetics of carbohydrate metabolism and growth in Eisemia foetida (Oligocheta: Lumbricidae). Heredity 61: 379-387.

Diehl W. J., Gaffney P. M. and Koehn R. K. 1986. Physiological and genetics aspects of growth in the mussel Mytilus edulis. I. Oxygen consumption, growth, and weight loss. Physiological Zoology 59: 201-211.

Diehl W. J., Gaffney P. M., McDonald J. H. and Koehn R. K. 1985. Relationship between weight standarized oxygen consumption and multiple-locus heterozygosity in the marine mussel Mytilus edulis L. (Mollusca). IIn: Proceedings of the 19th European Marine Biology Symposium. P. Gibbs, ed]. Cambridge University Press, Cambridge: 529-534.

Dobzhansky T. and Wallace B. 1953. The genetics of homeostasis in Drosophila. Proceedings of the National Academy of Sciences USA 39: 162-171.

Eanes W. F. 1978. Morphological variance and enzyme heterozygosity in the monarch butterfly. Nature 276: 263-264.

Eanes W. F. 1981. Enzyme heterozygosity and morhological variance. Nature 290; 609-610.

Eanes W. F. 1984. Viability interactions, in vivo activity, and the G6PD polymorhism in Drosophila melanogaster. Genetics 106: 95-107.

Fleischer R. C., Johnston R. F. and Klitz W. J. 1983. Allozymic heterozygosity and morphological variation in house sparrows. Nature 304: 628-630.

Feder J. L., Smith M. H., Chesser R. K., Godt M. J. and Asbury K. 1984. Biochemical genetics of mosquitofish. II. Demographic differentiation of populations in a thermally altered reservoir. Copeia 1984: 108-119.

Ferguson M. M. and Drahushchak L. R. 1990. Disease resistance and enzyme heterozygosity in rainbow trout. Heredity 64: 413-417.

Fitzsimmons N. N. 1992. Genetic factors, populations histories, and horn growth in Rocky Mountain bighorn sheep (Ovis canadensis canadensis). M Sc thesis University of Wyoming, Laramie: 1-76.

Fitzsimmons N. N., Buskirk S. and Smith M. H. 1995. Population history, genetic variability, and horn growth in bighorn sheep. Conservation Biology 9: 314-323. 
Frelinger J. A. 1972. The maintenance of transferin polymorphism in pigens. Proceedings of the National Academy of Sciences USA 69: 326-329.

Gajardo G. M. and Beardmore J. A. 1989. Ability to switch reproductive mode in Artemia is related to maternal heterozygosity. Marine Ecology Progress Series 55: 191-195.

Garton D. W. 1984. Relationship between multiple locus heterozygosity and physiological energetics of growth in the estuarine gastropod Thais haestomata. Physiological Zoology 57: 530-543.

Garton D. W., Koehn R. K. and Scott T. M. 1984. Multiple-locus heterozygosity and the physiological energetics of growth in the coot clam, Mulinia lateralis, from a natural population. Genetics 106: $445-455$.

Geist V. 1966. The evolutionary significance of mountain sheep horns. Evolution 20: 558-566.

Geist V. 1971. Moutain sheep: a study in behavior and evolution. University of Chicago Press, Chicago: 1-383.

Hall J. G. and Koehn R. K. 1983. The evolution of enzyme catalytic efficiency and adaptive inference from steady-state kinetic data. Evolutionary Biology 16: 53-96.

Handford P. 1980. Heterozygosity at enzyme loci and morphological variation. Nature 286: 261-262.

Hartl G. B., Lang G., Klein F. and Willing R. 1991. Relationships between allozymes, heterozygosity and morphological charcters in red deer (Cervus elaphus), and the influence of selective hunting on allele frequency distributions. Heredity $66: 343-350$.

Hartl G. B., Suchentrunk F., Willing R. and Penzek R. 1995. Allozyme heterozygosity and fluctuating asymmetry in the brown hare (Lepus euroapeus): a test of the developmental hoemostasis hypothesis. Proceedings of the Royal Society of London B. (in press)

Hartl G. B., Willing R. and Nadlinger K. 1994. Allozyes in mammalian population genetics and systematics: Indicative function of a marker system reconsidered. Molecular ecology and evolution: approches and applications. Birkenauer Verlag, Basel, Switzerland: 299-310.

Hawkins A. J., Bayne B. L. and Day A. J. 1986. Protein turnover, physiological energetics and heterozygosity in the blue mussel, Mytilus edulis: the basis of variable age-specific growth Proceedings of the Royal Society of London B 229: 161-176.

Hawkins A. J., Bayne B. L., Day A. J., Rusin J. and Worrall C. M. 1989. Genotype-dependent interrelations between energy metabolism, protein metabolism and fitness. IIn: Reproduction, genetics and distributions of marine organisms. J. S. Ryland and P. A. Tyler, eds]. Olsen and Olsen, Fredensborg, Denmark: 283-292.

Hilibish T. J. and Koehn R. K. 1985. Dominance in physiological phenotypes and fitness at an enzyme locus. Science 229: $52-54$.

Hogg J. T. 1987. Intrasexual competition and mate choice in Rocky Mountain bighorn sheep. Ethology 75: $119-144$.

Karl S. A. and Avise J. C. 1992. Balancing selectionat allozyme loci in oysters: implications from nuclear RFLPs. Science 256: 100-102

King D. P. F. 1985. Enzyme heterozygosity associated with anatomical character variance and growth in the herring (Clupea harengus L.). Heredity 54: 289-296.

Kobyliansky E. and Livshits G. 1985. Differential fertility and morphological constitution of spouses Zeitschrift für Morphologie und Anthropologie 76: 95-105

Kodiric-Brown A. and Brown J. H. 1984. Truth in advertising: the kinds of traits favored by sexual selection. American Naturalist 124: 303-323.

Koehn R. K. 1978. Physiology and biochemistry of enzyme variation: the interface of ecology and population genetics. [In: Ecological genetics: the interface. P. Brussard, ed]. Springer-Verlag, New York: 51-71.

Koehn R. K. and Bayne B. L. 1988. Towards a physiological and genetical understanding of the energetics of the stress response. Biology Journal of the Linnean Society 37: 157

Koehn R. K. and Shumway S. E. 1982. A genetic/physiological explanation for differential growth rate among individuals of the American oyster, Crassostera virginica (Gmelin.). Marine Biology Letters 3: $35-42$. 
Koehn R. K. Zera A. J. and Hall J. G. 1983. Enzyme polymorphism and natural selection. IIn: Evolution of genes and proteins. M. Nei and R. K. Koehn, eds]. Sinauer Associates Inc. Sunderland, Mass.: 115-136.

Labate J. and Eanes W. F. 1992. Direct measurement of vivo flux differences between electrophoretic variants of G6PD from Drosophila melanogaster. Genetics 132: 783-787.

Lansman R. A., Avise J. C., Aquadro C. F., Shapira J. F. and Daniel S. W. 1983. Extensive genetic variation in mitochondrial DNA's among geographic populations of the deer mouse, Peromyscus maniculatus. Evolution 37: 1-16.

Leary R. F., Allendorf F. W. and Knudsen K. L. 1983. Developmental stability and enzyme heterozygosity in rainbow trout. Nature 301: 71-72.

Leary R. F., Allendorf F. W. and Knudsen K. L. 1984. Superior developmental stability of heterozygotes at enzyme loci in salmonid fishes. American Naturalist 124: 540-551.

Leary R. F., Allendorf F. W. and Knudsen K. L. 1985. Inheritance of meristic variation and evolution of developmental stability in rainbow trout. Evolution 39: 308-314.

Leary R. F., Allendorf F. W. and Knudsen K. L. 1993. Null alleles at two lactate dehydrogenase loci in rainbow trout are associated with decreased developmental stability. Genetica 89: 5-15.

Leberg P., Smith M. H. and Rhodes O. E., Jr 1990. The association between heterozygosity and the growth of deer fetuses is not explained by effects of the loci examined. Evolution 44: 454-459.

Leberg P., Smith M. H. and Brisbin I. L., Jr 1992. Influence of sex, habitat, and genotype on growth patterns of white-tailed deer. [In: The biology of deer. R. D. Brown, ed]. Springer-Verlag, New York: 343-350.

Lerner I. M. 1954. Genetic homeostasis. Oliver and Boyd, Edinburgh: 1-154.

Livshits G. and Kobyliansky E. 1985. Lerner's concept of developmental homeostasis and the problem of heterozygosity level in natural populations. Heredity 55: 341-353.

Livshits G. and Smouse P. E. 1994. Relationship between fluctuating asymmetry, morphological modality and heterozygosity in an elderly Israeli population. [In: Developmental instability: its origins and evolutionary implications. T. A. Markow, ed]. Kluwer Academic Publishers, Dordrecht: 157-168.

Lydeard C. P., Leberg P. L. and Smith M. H. 1990. Effects of predation on population demography and genetics of eastern mosquitofish. Georgia Journal of Science 48: 144-151.

Manning J. T. and Chamberlain A. T. 1994. Fluctuating asymmetry in gorilla canines: a sensitive indicator of environmental stress. Proceedings of the Royal Society of London B 255: 189-193.

Manning J. T. and Hartley M. A. 1991. Symmetry and ornamentation are correlated in peacock's train. Animal Behaviour 42: 1020-1021.

Manning J. T. and Ockenden L. 1994. Fluctuating asymmetry in racehorses. Nature 370: 185-186.

Markowski J., Osmulski P., Duda W., Dyner E. and Świątecki A. 1990a. Could haptotypes be an indicator of health status of the brown hare populations? Lagomorph Newsletter 11: 14-16.

Markowski J., Osmulski P., Duda W., Dyner E., Świątecki A., Ułańska M. and Janiszewski T. 1990b. Relationship between haptoglobin polymorphism and health status of brown hare populations in Poland. Acta Theriologica 35: 214-224.

Messier S. and Mitton J. B. 1996. Heterozygosity at the malate dehydrogenase locus and developmental homeostasis in Apis mellifera. Heredity. (in press)

Mitton J. B. 1978. Relationship between heterozygosity for enzyme loci and variation of tiorphological characters in natural populations. Nature 273: 661-662.

Mitton J. B. 1993a. Theory and data pertinent to the relationship between heterozygosity and fitness. [In: The natural history of inbreeding and outbreeding. N. Thornhill, ed]. University of Chicago Press, Chicago: 17-41.

Mitton J. B. 1993b. Enzyme heterozygosity, metabolism, and developmental stability. Genetica 89: $47-65$.

Mitton J. B. 1994. Molecular approchaes to population biology. Annual Review of Ecology and Systematics 25: 45-69. 
Mitton J. B., Carey C. and Kocher T. D. 1986. The relation of enzyme heterozygosity to standard and active oxygen comsumption and body size of tiger salamanders, Ambystoma tigrinum. Physiological Zoology 59: 574-582.

Mitton J. B. and Grant M. C. 1984. Associations among protein heterozygosity, growth rate, and developmental homeostasis. Annual Review of Ecology and Systematics 15: 479-499.

Mitton J. B. and Koehn R. K. 1985. Shell shape variation in the blue mussel, Mytilus edulis L., and its association with enzyme heterozygosity. Journal of Experimental Marine Biology and Ecology 90: $73-80$.

Mitton J. B. and Pierce B. A. 1980. The distribution of individual heterozygosity in natural populations, Genetics 95: 1043-1054.

Mitton J. B., Schuster W. S. F., Cothran E. G. and De Fries J. 1993. The correlation in heterozygosity between parents and their offspring. Heredity 71: 59-63.

Møller A. P. 1988. Female choice selects for male sexual tail ornaments in the monogamous swallow. Nature 332: 640-642.

Møller A. P. 1989. Viability costs of male tail ornaments in a swallow. Nature 339: 132-135.

Møller A. P. 1990a. Male tail length and female mate choice in the monogamous swallow Hirundo rustica. Animal Behaviour 39: 458-465.

Møller A. P. 1990b. Fluctuating asymmetry in male sexual ornaments may reliably reveal male quality. Animal Behaviour 40: 1185-1187.

Møller A. P. 1990c. Effects of an haematophagus mite on the barn swallow (Hirundo rustica): A test of the Hamilton and Zuk hypothesis. Evolution 44: 771-784.

Møller A. P. 1991a. Sexual ornament size and the cost of fluctuating asymmetry. Proceedings of the Royal Society of London B 243: 59-62.

Møller A. P. 1991b. Viability is positively related to degree of ornamentation in male swallows. Proceedings of the Royal Society of London B 243:145-148.

Møller A. P. 1993. Morphology and sexual selection in the barn swallow Hirundo rustica in Chernobyl, Ukraine. Proceedings of the Royal Society of London B 252: 51-57.

Møller A. P. 1994a. Sexual selection and the barn swallow. Oxford University Press, Oxford: 1-365.

Møller A. P. 1994b. Sexual selection in the barn swallow (Hirundo rustica). IV. Patterns of fluctuating asymmetry and selection against asymmetry. Evolution 48: 658-670.

Mulvey M., Goater T. M., Esch G. W. and Crews A. E. 1987. Genotype frequency differences in Halipegus occidualis - infected and uninfected Helisoma anceps. Journal of Parasitology 73: 751-761.

Mulvey M., Keller G. P. and Meffe G. K. 1994. Single- and multiple-locus genotypes and life-history responses of Gambusia holbrooki reared at two temperatures. Evolution 48: 1810-1819.

Novak J. M., Rhodes O. E., Jr, Smith M. H. and Chesser R. K. 1993. Morphological asymmetry in mammals: genetics and homeostasis reconsidered. [In: Ecological genetics in mammals. G. B. Hartl and J. Markowski, eds]. Acta Theriologica 38, Suppl. 2: 7-18.

Ozenyuk N. D., Dyomin V. I., Prokofyev E. A and Androsova I. M. 1992. Energy homeostasis and stability development. Acta Zoologica Fennica 191: 167-176.

Petrie M. 1994. Improved growth and survival of offspring of peacocks with more elaborate trains. Nature 371: 598-599.

Petrie M., Halliday T. R. and Sanders C. 1991. Peahens prefer peacocks with elaborate trains. Animal Behaviour 41: 323-331.

Pogson G. H. 1991. Expression of overdominance for specific activity at phosphoglucomutase-2 locus in the pacific oyster Crassostera gigas. Genetics 128: 133-141.

Pogson G. H., Mesa K. A. and Boutilier R. G. 1995. Genetic population structure and gene flow in the atlantic cod Gadus morhua: a comparison of allozyme and nuclear RFLP loci. Genetics 139: $375-385$. 
Pogson G. H. and Zouros E. 1994. Allozyme and RFLP heterozygosities as correlates of growth in the scallop Plactopecten magellanicus: A test of the associative overdominance hypothesis. Genetics 137: 221-231.

Polak M. 1994. Parasities increse fluctuating asymmetry in male Drosophila nigrospiracula: implications for sexual selection. [In: Developmental instability: its origins and evolutionary implications. T. A. Markov, ed]. Kluwe Academic Publishers, Dordrecht: 257-267.

Powers D. A., Smith M., Gonzalez-Villasenor I., DiMichele L., Crawford D., Bernardi G. and Laureman T. 1994. A multidisciplinary approach to the selection/neutralist controversy using the model teleost Fundulus heteroclitus. Oxford Surveys in Evolutionary Biology: 43-107.

Preleuthner M., Pinsker W., Kruckenhauser L., Miller W. J. and Pros1 H. 1995. Alpine marmots in Austria. The present population structure as a result of the postglacial distribution history. [In: Ecological genetics in mammals II. G. B. Hartl and J. Markowski, eds]. Acta Theriologica, Suppl. 3: $87-100$.

Reeb C. A. and Avise J. C. 1990. A genetic discontinuity in a continuoisly distributed species: mitochondrial DNA in the America oyster, Crassostrea virginica. Genetics 124: 397-406.

Robertson F. and Reeve E. C. 1952. Heterozygosity, environmental variation and heterosis. Nature 170: $286-287$.

Scribner K. T. and Smith M. H. 1990. Genetic variability and antler development. [In: Horns, pronghorns and antlers. G. A. Bubenik and A. B. Bubenik, eds]. Springer, New York: 460-473.

Scribner K. T., Smith M. H. and Johns P. E. 1984. Age, condition, and genetics effects on incidence of spiked bucks. Proceedings of the Annual Conference of Southeastern Fisheries and Wildlife Agencies 38: 23-32.

Scribner K. T., Smith M. H. and Johns P. E. 1989. Environmental and genetic components of antler growth in white-tailed deer. Journal of Mammalogy 70: 284-291.

Smith M. H., Chesser R. K., Cothran E. G. and Johns P. E. 1982. Genetic variability and antler growth in antural population of white-tailed deer. [In: Antler development in Cervidae. R. D. Brown, ed]. Caesar Kleberg Wildlife Research Institute, Kingsville, Texas: 365-387.

Smith M. H., Scribner K. T., Johns P. E. and Rhodes O. E., Jr 1991. Genetics and antler development. [In: Transactions of the 18th Congress of International Union of Game Biologists, Kraków, Poland, 1987. B. Bobek, K. Perzanowski and W. Regelin, eds]. Świat Press, Kraków, Poland: 365-387.

Templeton A. R. 1982. Adaptation and integration of evolutionary forces. [In: Perspectives on evolution. R. Milkman, ed]. Sinauer Associates, Inc., Sunderland, Mass.: 15-31.

Teska W. R., Smith M. H. and Novak J. M. 1990. Food quality, heterozygosity, and fitness correlates in Peromyscus polinotus. Evolution 44: 1318-1325.

Thornhill R. 1992. Fluctuating asymmetry and mating system of the Japanese scorpionfly, Panorpa japonica. Animal Behaviour 44: 867-869.

Waddington C. M. 1953. genetic assimilation of an acquired character. Evolution 7: 118-126.

Ward R. D., Sarfarazi D. M., Azimi-Garkani C. and Beardmore J. A. 1985. Population genetics of polymorphism in Cardiff newborn: Relationship between blood group and allozyme heterozygosity and birth weight. Human Heredity 35: 171-177.

Watt W. B., Cassin R. C. and Swan M. S. 1983. Adaptation at specific loci. III. Field behavior and survivorship differences among Colias PGI genotypes are predictable from in vitro biochemistry. Genetics 103: 725-739.

Watt W. B. 1983. Adaptation at specific loci. II. Demographic and biochemical elements in the maintenance of the Colias PGI Polymorphism. Genetics 103: 691-724

Watt W. B. 1992. Eggs, enzymes, and evolution-natural genetic variants change insect frcundity. Proceedings of the National Academy of Sciences USA 89: 10608-10612.

Watt W. B., Carter P. A. and Donohue K. 1986. Females' choice of "good genotypes" as mates is promoted by an insect mating system. Science 233: 1187-1190.

Wooten M. C. and Smith M. H. 1986. Fluctuating asymmetry and genetic variability in a natural population of Mus musculus. Journal of Mammalogy 67: 725-732. 
Yezerinac S. M., Lougheed S. C. and Handford P. 1992. Morphological variability and enzyme heterozygosity: individual and population level correlations. Evolution 46: 1959-1964.

Zamer W. E. and Hoffman R. J. 1989. Allozyme of glucose-6-phosphate isomerase differentially modulate pentose-shunt metabolism in the sea anemone Metridium senile. Proceedings of the National Academy of Sciences USA 86: 2737-2741.

Zapata C., Gajardo G. and Breadmore J. A. 1990. Multilocus heterozygosity and sexual selection in the brine shrimp Artemia franciscana. Mar. Ecol. Prog. Ser. 62: 211-217.

Zouros E. and Foltz D. W. 1987. The use of allelic isozyme varition for the study of heterosis. [In: Isozymes: Current topics in biological and medical research. M. C. Rattzzi, J. G. Scandalios and G. S. Whitt, eds]. Alan R. Liss, Inc., New York, vol. 13: 2-59.

Zouros E. and Pogson G. H. 1993. The present status of the relationship between heterozygosity and heterosis. [In: Genetics and evolution of aquatic organisms. A. Beaumont, ed]. Chapman and Hall, London: $135-146$.

Zuk M., Johson K., Thornhill R. and Ligon J. D. 1990. Mechanisms of female choice red jungle fowl. Evolution 44: 472-485.

Received 21 August 1995, accepted 15 September 1995. 